\title{
Penambatan Molekuler dan Simulasi Dinamika Molekuler Senyawa Dari Genus Nigella Terhadap Penghambatan Aktivitas Enzim Protease HIV-1
}

\author{
(Molecular Docking and Molecular Dynamics Simulation of Compounds from Nigella Genus on \\ Protease HIV-1 Enzyme Inhibitors)
}

\author{
Muhammad Sulaiman Zubair ${ }^{1 *}$, Saipul Maulana ${ }^{1}$, Alwiyah Mukaddas ${ }^{1}$ \\ ${ }^{I}$ Fakultas Matematika dan Ilmu Pengetahuan Alam, Universitas Tadulako, Palu, Indonesia. \\ E-mail: sulaiman_zubair80@yahoo.co.id \\ Article Info: \\ Received: 19 Januari 2020 \\ in revised form: 25 Januari 2020 \\ Accepted: 07 Maret 2020 \\ Available Online: 07 Maret 2020 \\ Keywords: \\ Nigella \\ Molecular Docking \\ Molecular Dynamics \\ Protease HIV-1 \\ Corresponding Author: \\ Muhammad Sulaiman Zubair \\ Fakultas Matematika dan Ilmu \\ Pengetahuan Alam \\ Universitas Tadulako \\ Palu \\ 90245 \\ Indonesia \\ email: \\ sulaiman_zubair80@yahoo.co.id

\begin{abstract}
Nigella plant genus has potential as anti-HIV. One species of Nigella, Nigella sativa has been reported to have HIV-1 protease enzyme inhibitory activity. This research aims to determine the compounds of the Nigella genus that have activity as HIV-1 protease enzyme inhibitory activity through molecular docking method by Autodock Vina and to compare interaction stability through molecular dynamics simulations by AMBER. The metabolite of the Nigella genus was obtained from the KnapSack website, and enzyme model was obtained from the Protein Data Bank (3NU3). The results of molecular docking found the lowest affinity energy of Nigella compound is Nigellidine 4-O-sulfite $(-13.4 \mathrm{kcal} / \mathrm{mol})$. Meanwhile, the affinity energy of the ligand native (Amprenavir) was -12.1 $\mathrm{kcal} / \mathrm{mol}$. The lowest affinity energy of Nigellidine 4-O-sulfite might be predicted to have potency as an HIV-1 Protease inhibitor. Molecular dynamics simulation showed Root Mean Square Fluctuation (RMSF) value of Nigellidine 4-O-sulfite with the amino acid active site is $0.4064 \AA$ for ASP:25 and $0.5667 \AA$ for ASP: 125 . Whereas RMSF ligand native with the amino acid active site, ASP: 25 is $0.3647 \AA$ and ASP: 125 is $0.3639 \AA$. The higher RMSF value of Nigellidine 4-O-sulfite describes the lower interaction stability than the ligand native.
\end{abstract}

Copyright (C) 2019 JFG-UNTAD

This open access article is distributed under a Creative Commons Attribution (CC-BY-NC-SA) 4.0 International license.

How to cite (APA $6^{\text {th }}$ Style):

Zubair, M. S., Maulana, S., Mukaddas, A. (2020). Penambatan Molekuler dan Simulasi Dinamika Molekuler Senyawa Dari Genus Nigella Terhadap Penghambatan Aktivitas Enzim Protease HIV-1. Jurnal Farmasi Galenika :Galenika Journal of Pharmacy (e-Journal), 6(1), 132-140. doi:10.22487/j24428744.2020.v6.i1.14982 


\section{ABSTRAK}

Nigella merupakan genus tumbuhan yang berpotensi sebagai anti HIV. Salah satu spesies dari genus ini yaitu Nigella sativa telah diteliti memiliki aktivitas penghambatan enzim protease HIV-1. Penelitian ini bertujuan untuk menentukan senyawa dari genus Nigella yang berpotensi sebagai inhibitor enzim protease HIV-1 melalui penambatan molekuler menggunakan program Autodock Vina dan mengetahui kestabilan interaksi melalui simulasi dinamika molekuler menggunakan program AMBER. Data senyawa kimia genus Nigella diperoleh dari situs KnapSAck, dan model enzim diunduh dari Protein Data Bank (3NU3). Hasil molecular docking diperoleh energi afinitas paling terendah dari senyawa Nigellidine 4-O-sulfite $(-13,4 \mathrm{kkal} / \mathrm{mol})$. Sedangkan energi afinitas ligan standar (Amprenavir) sebesar -12,1 kkal/mol. Afinitas yang lebih rendah membuat Nigellidine 4-O-sulfite diprediksi berpotensi menjadi inhibitor Protease HIV-1. Hasil simulasi dinamika molekuler diperoleh nilai Root Mean Square Fluctuation (RMSF) berturut-turut Nigellidine 4-O-sulfite dengan asam amino sisi aktif enzim sebesar 0,4064 ̊ untuk ASP:25 dan 0,5667 ̊̊ untuk ASP:125. Sedangkan RMSF interaksi ligan standar dengan asam amino sisi aktif enzim yaitu ASP:25 sebesar 0,3647 $\AA$ dan ASP:125 sebesar 0,3639 ̊. Nilai RMSF Nigellidine 4-O-sulfite yang lebih besar menggambarkan kestabilan interaksi yang lebih rendah dibandingkan ligan standar.

Kata kunci: Nigella, Molecular Docking, Molecular Dynamics, Protease HIV-1

\section{PENDAHULUAN}

AIDS (Acquired Immune Deficiency Syndrome) adalah sekumpulan gejala penyakit yang timbul karena turunnya kekebalan tubuh yang disebabkan oleh infeksi HIV (Kemenkes RI, 2014). HIV (Human Immunodeficiency Virus) adalah virus yang menyerang sel darah putih yang menyebabkan turunnya kekebalan tubuh manusia. Jumlah penderita HIV di Indonesia dari bulan Oktober sampai dengan Desember 2017 sebanyak 14.640 orang, dan AIDS sebanyak 4.725 orang. Pola penularan HIV tertinggi berdasarkan kelompok umur paling banyak terjadi pada kelompok usia produktif 25-49 tahun $(69,2 \%)$, diikuti kelompok usia 20-24 tahun $(16,7 \%)$, dan kelompok $>50$ tahun $(7,6 \%)$ dengan rasio penderita HIV antara laki-laki dan perempuan adalah $2: 1$. Sedangkan di Sulawesi Tengah kasus HIV mencapai 200 kasus, dan AIDS mencapai 144 kasus (Kemenkes RI, 2017).

Penanganan infeksi HIV saat ini adalah menggunakan terapi antiretroviral dengan aktivitas tinggi. Pemberian obat antiretroviral (ARV) sejauh ini belum efektif membunuh HIV, pengobatan ini hanya mampu menghambat perkembangan virus (Depkes, 2006). Obat ARV bekerja dengan menekan replikasi virus penderita, dan menghambat progresivitas infeksi (WHO, 2018). Salah satu mekanisme kerja obat ARV yaitu dengan menghambat kerja enzim protease yang berperan dalam maturasi virus (Ghosh et al., 2017). Penghambatan enzim protease berdampak pada virus yang immature sehingga virus menjadi bentuk yang non infeksius (Pandey et al., 2017). Oleh karena itu, pentingnya enzim protease HIV dalam siklus hidup virus menjadikan enzim protease sebagai target ideal untuk pengobatan penyakit HIV (Yilmaz et al., 2017).

Beberapa komponen senyawa tanaman dari bahan alam memiliki potensi untuk menjadi senyawa obat baru yang menghambat kerja enzim HIV (Kurapati et al., 2016). Salah satu genus tumbuhan yang memiliki potensi sebagai anti HIV adalah Nigella. Ekstrak biji Nigella Sativa dilaporkan memiliki aktivitas sebagai inhibitor enzim protease HIV-1 (Kusumoto et al., 1995). Studi kasus yang dilaporkan oleh Onifade et al (2013) menunjukkan bahwa pemberian terapi selama 6 bulan menggunakan ramuan yang mengandung biji Nigella sativa sebanyak $10 \mathrm{ml}$ dua kali sehari, memberikan hasil pemeriksaan berupa virus HIV tidak terdeteksi dan kadar CD4 mendekati normal. Pada penelitian ini, dilakukan pengujian secara in silico senyawa-senyawa anti HIV dari tumbuhan genus Nigella sebanyak 45 senyawa menggunakan metode penambatan molekuler yang selanjutnya dianalisa secara dinamika molekuler untuk mengetahui kestabilan interaksi dalam ruang dan waktu tertentu. 


\section{METODE PENELITIAN}

\section{Alat dan Bahan}

Bahan yang digunakan dalam penambatan molekuler berupa model enzim protease virus HIV-1 diunduh dari situs Protein Data Bank (http://www.rcsb.org/) (kode : 3NU3), data struktur senyawa kimia dari tanaman genus Nigella yang diperoleh dari situs KNApSAcK (http://kanaya.naist.jp/KNApSAcK/) dengan kata kunci Nigella sejumlah 45 senyawa. Perangkat lunak yang digunakan yaitu, Sistem Operasi Windows 7 dan Linux Fedora, Chemdraw, Chem3D, MarvinView, Autodock Tools, Autodock Vina, PyMol, Biovia Discovery Studio 2017, Amber Tools, serta Terminal Linux. Perangkat keras yang digunakan pada penelitian ini adalah komputer Laboratorium Penelitian Jurusan Farmasi UNTAD dengan spesifikasi processor Intel (R) Core i52400 CPU @ 3.10GHz (4 CPUs), memory 2048 MB RAM.

\section{Metode}

\section{Penyiapan Senyawa Metabolit}

Senyawa metabolit yang terdapat pada genus Nigella yang telah diketahui (sebanyak 45 senyawa metabolit) diunduh pada website KNApSAcK, kemudian mengoptimalkan struktur senyawa metabolit menggunakan program Chem3D.

\section{Preparasi struktur protein}

Enzim Protease HIV-1 diunduh pada website www.rscb.org dengan kode PDB; 3NU3. Kemudian, digunakan perangkat lunak BIOVIA Discovery Studio 2017 untuk memisahkan residu pelarut (air), ligan standar, serta residu non-standar lainnya dari enzim sehingga diperoleh berkas ligan standar dan enzim tanpa residu pelarut dan non standar lain. Masing-masing berkas selanjutnya dioptimasi dengan perangkat lunak Autodock Tools..

\section{Analisis dan Visualisasi Redocking Molekul Ligan Standar}

Ligan standar dan enzim yang telah disiapkan selanjutnya didocking berdasarkan koordinat interaksi ikatan ligan-enzim menggunakan Autodock Vina. Posisi dan orientasi ligan standar pada enzim yang berinteraksi dengan asam-asam amino divisualisasikan dengan perangkat lunak BIOVIA Discovery Studio 2017. Kemudian, diperoleh nilai RMSD (Root Mean Square Deviation) dengan perangkat lunak PyMOL. Bila hasil penambatan ligan standar memiliki nilai RMSD <2A, maka protokol penambatan dapat diterima atau dinyatakan valid (Zubair et al., 2016).

\section{Penyiapan Ligan Senyawa Metabolit Tanaman Genus Nigella}

Struktur senyawa metabolit genus Nigella yang telah diketahui (sebanyak 45 senyawa metabolit) pada database KNApSAcK diunduh, dan dioptimasi strukturnya dengan perangkat lunak Chem3D menggunakan metode MM2. Struktur tersebut kemudian diskrining awal berdasarkan kriteria Lipinski, Aturan Lipinski pada dasarnya menjelaskan tentang sifat senyawa yang aktif secara oral dan paramater yang digunakan dalam menentukan sifat fisikokimianya (Lipinski, 2004). Aturan Lipinski bertujuan untuk mengevaluasi suatu senyawa kimia yang memiliki aktivitas farmakologi yang dapat aktif jika diberikan secara oral pada manusia (Singh et al., 2013). Senyawa/Ligan dianggap memiliki sifat fisikokimia yang baik jika memenuhi aturan Lipinski dengan kriteria yaitu; berat molekul $<500$ gram/mol, jumlah grup donor proton ikatan hidrogen $<5$, jumlah grup akseptor proton ikatan hidrogen $<10$, dan nilai koefisien partisi $(\log P)<5$. Pada penelitian ini hanya senyawa yang memenuhi paling sedikit 3 dari 4 aturan yang akan dilakukan penambatan molekuler. 


\section{Penambatan Molekul Senyawa Uji}

Penambatan molekuler senyawa uji dilakukan dengan menggunakan Autodock Vina, dengan koordinat koordinat $\mathrm{x}=16,751, \mathrm{y}=23,353, \mathrm{z}=17,611$ dan grid box sebesar 50 x 50 x $50 \AA$.

\section{Analisis dan Visualisasi Penambatan Molekul Senyawa Uji}

Nilai skor penambatan dari masing-masing senyawa uji tersebut kemudian dibandingkan dengan skor penambatan ligan standar yang diperoleh dari protokol redocking penambatan sebelumnya. Hasil penambatan dianalisis dan divisualisasi model interaksi ligan-reseptornya dengan menggunakan Autodock Tools dan BIOVIA Discovery Studio 2017.

\section{Simulasi Dinamika Molekuler}

Simulasi dinamika molekuler penambatan kompleks enzim protease dengan ligan dilakukan dengan menggunakan program AMBER MD melalui beberapa tahapan, yaitu:

\section{Persiapan berkas masukan}

Dalam simulasi dinamika molekuler berkas masukan yang harus disiapkan meliputi persiapan berkas enzim-ligan hasil penambatan, serta topologi dan koordinat menggunakan program Amber Tools.

\section{Minimisasi Energi}

Pada tahap minimisasi energi, digunakan berkas topologi dan koordinat ligan, makromolekul, dan kompleks ligan-makromolekul menggunakan program Amber Tools yang berlangsung dalam dua tahap, dimana tahap pertama merupakan minimisasi terhadap molekul air sebanyak 1000 steps, dan minimisasi tahap kedua merupakan minimisasi seluruh sistem ligan-enzim dan molekul air juga sebanyak 1000 steps.

\section{Ekuilibrasi}

Ekuilibrasi dilakukan dengan menggunakan program Amber dan berlangsung dalam 3 tahapan. Pada tahapan pertama, dilakukan ekuilibrasi untuk membuat volume yang konstan dan menaikkan suhu dari $0^{\circ} \mathrm{K}$ menjadi $300^{\circ} \mathrm{K}$ (5000 steps). Ekuilibrasi kedua (5000 steps) dan ketiga (50000 steps) dilakukan untuk membuat seluruh sistem ligan-enzim dan molekul air berada pada suhu dan tekanan yang konstan.

\section{Produksi}

Proses produksi simulasi dinamika molekuler dilakukan dengan perangkat lunak sander. Pada tahap produksi ini, dilakukan dalam 10 langkah dimana masing-masing langkah dilakukan dengan 100000 steps untuk mencapai waktu total simulasi sebesar $2 \mathrm{~ns}$.

\section{Analisis Hasil Simulasi Dinamika Molekuler}

Hasil simulasi dinamika molekuler berupa berkas keluaran dan berkas trajectory yang dianalisa dengan program cpptraj dan VMD dari AmberTools, dengan parameter yang dianalisis adalah fluktuasi energi potensial, RMSD (Root Mean Square Deviation), RMSF (Root Mean Square Fluctuation), dan perubahan jarak interaksi. 


\section{HASIL DAN PEMBAHASAN}

Penambatan divalidasi dengan menambatkan ligan standar sebagai protokol redocking dengan enzim protease HIV-1 yang telah dipersiapkan sebelumnya. Ligan standar (Amprenavir) digunakan sebagai protokol penambatan untuk memprediksi posisi dan interaksi ligan-enzim. Penambatan dilakukan menggunakan Autodock Vina yang diakses melalui Cygwin. Selanjutnya dilihat nilai RMSD (Root Mean Square Deviation), nilai RMSD digunakan untuk mengukur kemiripan koordinat (pose) antara dua atom (Kufareva and Abagyan, 2012). Pada gambar 1 menunjukkan bahwa hasil redocking ligan

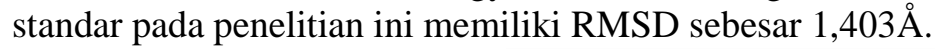

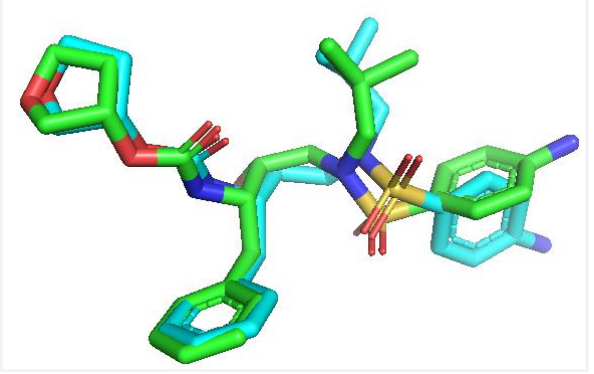

Gambar 1. Hasil RMSD dari ligan standar (nilai RMSD = 1,403

Pada penelitian ini terdapat 45 senyawa dari genus Nigella yang diperoleh dari situs KNApSAcK yang digunakan sebagai senyawa uji. Sebelum dilakukan penambatan molekuler, seluruh senyawa uji tersebut diskrining awal terlebih dahulu menggunakan aturan Lipinski. Aturan Lipinski bertujuan untuk mengevaluasi suatu senyawa kimia yang memiliki aktivitas farmakologi yang dapat aktif jika diberikan secara oral pada manusia (Singh et al., 2013). Jika suatu senyawa kimia memenuhi kriteria aturan Lipinski, maka senyawa tersebut dianggap memiliki potensi dapat masuk ke dalam membran sel dan diserap oleh tubuh (Chairunnisa dan Runadi, 2017). Senyawa yang memenuhi paling sedikit 3 dari 4 aturan yang akan dilakukan penambatan molekuler.

Berdasarkan hasil penambatan molekuler senyawa metabolit genus Nigella diperoleh 1 senyawa yang berpotensi sebagai inhibitor enzim protease HIV-1. Senyawa uji yang memiliki potensi sebagai inhibitor yaitu Nigellidine 4-O-sulfite dengan energi afinitas sebesar -13,4 kkal/mol, sedangkan ligan standar (Amprenavir) memiliki energi afinitas sebesar -12,1 kkal/mol. Senyawa aktif berpotensi sebagai inhibitor jika memiliki nilai energi afinitas yang lebih rendah dibandingkan ligan standar (Ramadhan, 2018). Senyawa tersebut selanjutnya dianalisa secara dinamika molekuler untuk mengetahui kestabilan interaksinya. 

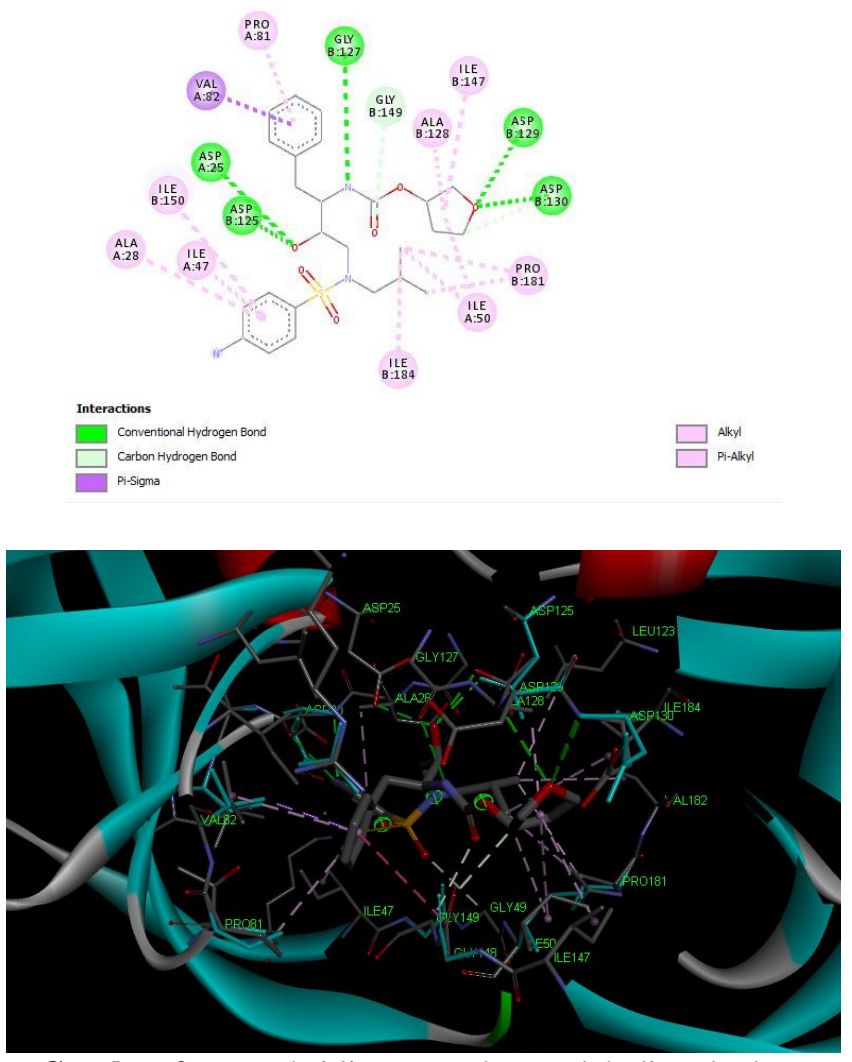

Gambar 2. Interaksi ligan standar setelah ditambatkan

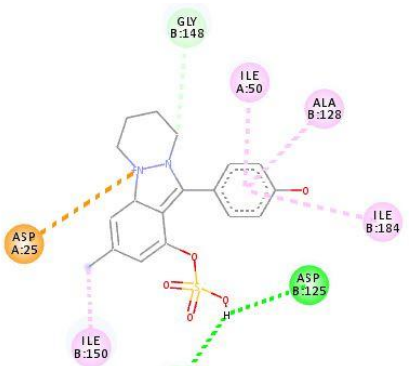

(6i2)

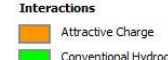

Conventional Hydrogen Bond

Carbon Hydrogen Bond

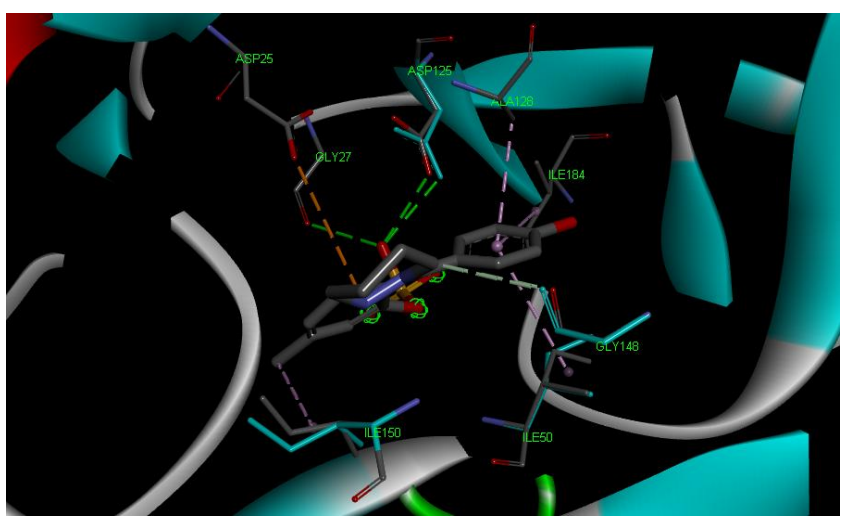

Gambar 3. Interaksi Nigellidine 4-O-sulfite setelah ditambatkan 
Pada Gambar 2 menunjukkan bahwa model interaksi ligan standar dan enzim setelah ditambatkan menunjukkan bahwa terjadi interaksi berupa ikatan hidrogen (ASP:25, ASP:125, GLY:127, ASP:130, ASP:129, GLY:149) dan interaksi hidrofobik yaitu Pi-Sigma (VAL:82), Alkyl/Pi-Alkyl (ILE:147, ALA:128, PRO:181, ILE:50, ILE:184, ALA:28, ILE:47, ILE:150, PRO:81). Interaksi Nigellidine 4-Osulfite dengan enzim protease HIV-1 berupa ikatan hidrogen (ASP:125, GLY:27, GLY:148), interaksi elektrostatik (ASP:25), dan interaksi hidrofobik yaitu Alkyl/Pi-Alkyl (ILE:50, ALA:128, ILE:184, ILE:47, ILE:150) seperti yang ditunjukkan pada gambar 3.

Hasil penambatan molekuler senyawa Nigellidine 4-O-sulfite dan ligan standar dengan enzim selanjutnya dianalisa secara dinamika molekuler. Analisa dinamika molekuler bertujuan untuk mengetahui kestabilan interaksi ligan-reseptor, hal ini dilakukan karena penambatan molekuler belum dapat memberikan informasi terkait kestabilan interaksi ligan-reseptor terhadap ruang dan waktu. Parameter yang digunakan untuk mengevaluasi kestabilan interaksi ligan-enzim pada simulasi dinamika molekuler adalah Root Mean Square Fluctuation (RMSF).

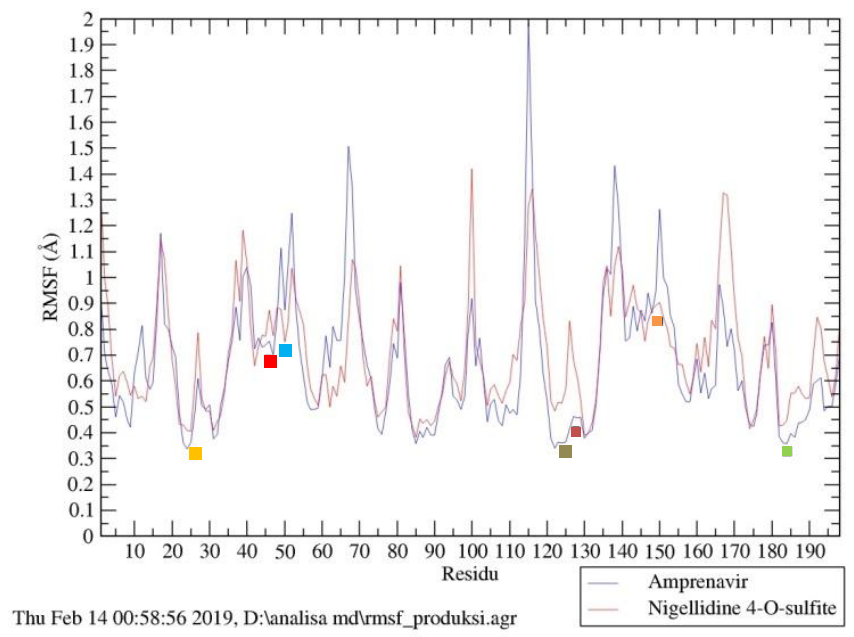

\author{
Daerah Interaksi \\ ASP:25 \\ I ILE:47 \\ ILE:50 \\ ASP: 125 \\ ALA: 128 \\ ILE: 150 \\ ILE: 180
}

Gambar 4. Grafik RMSF terhadap waktu selama proses ekuilibrasi dalam waktu simulasi 2000 piko detik

Tabel 1. Nilai RMSF hasil dinamika molekuler ligan standar dan Nigellidine 4-O-sulfite terhadap asam amino sisi aktif enzim protease HIV-1

\begin{tabular}{cccccccc}
\hline \multirow{2}{*}{ Ligan } & \multicolumn{7}{c}{ RMSF $(\mathbf{A})$} \\
\cline { 2 - 8 } & ASP:25 & ASP:125 & ILE:47 & ILE:50 & ALA:128 & ILE:150 & ILE:180 \\
\hline $\begin{array}{c}\text { Ligan } \\
\text { standar }\end{array}$ & 0,3647 & 0,3639 & 0,7002 & 0,8746 & 0,4564 & 1,2644 & 0,8267 \\
\hline $\begin{array}{c}\text { Nigellidine } \\
\text { 4-O-sulfite }\end{array}$ & 0,4064 & 0,5667 & 0,7757 & 0,7514 & 0,6115 & 0,9042 & 0,894 \\
\hline
\end{tabular}

Parameter RMSF (Root Mean Square Fluctuation) dievaluasi untuk mengetahui fluktuasi interaksi ligan dengan asam amino pada enzim selama simulasi. Berbeda dengan RMSD, RMSF dihitung terhadap masing-masing residu penyusun protein yakni melihat seberapa besar fluktuasi pergerakan masing-masing residu selama simulasi berlangsung. Secara umum, nilai RMSF menggambarkan fleksibilitas interaksi ligan dengan setiap residu asam amino (Rex, 2009). Nilai RMSF ligan standar dan Nigellidine 4-O-sulfite terhadap asam amino enzim protease HIV-1 dapat dilihat pada Tabel 1. Pada gambar 4 menunjukkan bahwa terjadi fluktuasi interaksi antara ligan dengan residu asam amino 
dalam enzim. Interaksi antara amprenavir maupun Nigellidine 4-O-sulfite dengan asam amino yang bertindak sebagai sisi katalitik enzim protease HIV-1 yaitu residu ASP:25 dan ASP:125, serta daerah ikatan lain berupa residu ILE:47, ILE:50, ALA:128, ILE:150, ILE:180 yang berperan sebagai kantung (pocket) ikatan memiliki nilai RMSF yang rendah seperti yang ditunjukkan pada gambar 4. Semakin rendah nilai RMSF, maka semakin stabil interaksi antara ligan dengan asam amino tersebut (Junaid et al., 2014). Kantung ikatan dalam enzim protease HIV-1 bersifat hidrofobik, adanya interaksi antara protease inhibitor dengan asam amino hidrofobik dalam kantung ikatan dapat meningkatkan afinitasnya (Ko et al., 2011).

\section{KESIMPULAN}

Senyawa Nigellidine 4-O-sulfite dari spesies Nigella sativa berpotensi memiliki aktivitas penghambatan terhadap enzim protease HIV-1 yang diuji secara in silico melalui penambatan molekuler dengan program Autodock Vina. Hasil simulasi dinamika molekuler menggambarkan bahwa senyawa Nigellidine 4-O-sulfite kurang stabil berinteraksi dengan sisi katalitik enzim protease HIV-1.

\section{DAFTAR PUSTAKA}

Chairunnisa, A., \& Runadi, D. (2017). Aktivitas Kalkon terhadap Reseptor Esterogen $\beta$ (Er- $\beta$ ) Sebagai Antikanker Payudara Secara In Vitro Dan In Silico: Review. Farmaka, 14, 1-8.

Depkes RI. (2006). Pelayanan Kefarmasian untuk Orang Dengan HIV/AIDS (ODHA). Jakarta: Departemen Kesehatan Republik Indonesia.

Ghosh, A. K., Osswald, H. L., \& Prato, G. (2017). Recent Progress in the Development of HIV-1 Protease Inhibitors for the Treatment of HIV/AIDS, 59 (11), 5172-5208. https://doi.org/10.1021/acs.jmedchem.5b01697.Recent

Junaid, M., Muhseen, Z. T., Ullah, A., Wadood, A., Liu, J., \& Zhang, H. (2014). Molecular modeling and molecular dynamics simulation study of the human Rab9 and RhoBTB3 C-terminus complex. Biomedical Informatics, 10(12), 757-763.

Kemenkes RI. (2014). Infodatin AIDS. Jakarta: Pusat Data dan Informasi Kementerian Kesehatan Republik Indonesia.

Kemenkes RI. (2017). Laporan Perkembangan HIV-AIDS \& Infeksi Menular Seksual (IMS) Triwulan IV Tahun 2017. Jakarta: Kementerian Kesehatan Republik Indonesia.

Ko, G. M., Reddy, A. S., Kumar, S., Bailey, B. A., \& Garg, R. (2011). Computational Analysis of HIV-1 Protease Protein Binding Pockets. J Chem Inf Model, 50 (10), 1759-1771. https://doi.org/10.1021/ci100200u.Computational

Kufareva, I., \& Abagyan, R. (2012). Methods of protein structure comparison. Methods Mol Biol, 857, 231-257. https://doi.org/10.1007/978-1-61779-588-6

Kurapati, K. R. V, Atluri, V. S., Samikkannu, T., \& Garcia, G. (2016). Natural Products as Anti-HIV Agents and Role in HIV-Associated Neurocognitive Disorders (HAND): A Brief Overview, 6, 1-14. https://doi.org/10.3389/fmicb.2015.01444

Kusumoto, I. T., Nakabayashi, T., Kida, H., Miyashiro, H., Namba, T., \& Shimotohno, K. (1995). Screening of Various Plant Extracts used in Ayurvedic Medicine for Inhibitory Effects on Human Immunodeficiency Virus Type 1 (HIV-1) Protease, 9, 180-184.

Onifade, A. A., Jewell, A. P., \& Adedeji, W. A. (2013). Nigella Sativa Concoction Induced Sustained 
Seroreversion in HIV Patient, 10, 332-335

Pandey, D., Chouhan, U., \& Verma, N. (2017). HIV Infection: A Review of their Inhibitors Progression. Biomedical \& Pharmacology Journal, 10(2), 749-758.

Ramadhan, A. (2018). Skrining Virtual Penghambat Enzim Xantin Oksidase (XO) dan Siklooksigenase-2 (COX-2) dari Senyawa Tanaman Kelor (Moringa oleifera Lam.). Skripsi. Universitas Tadulako, Palu.

Rex, R. (2009). Quantification of structure / dynamics correlation of globular proteins. Bachelor-und Masterarbeiten. Georg-August-Universität Göttingen.

Singh, S., Gupta, A. K., \& Verma, A. (2013). Molecular Properties and Bioactivity score of the Aloe vera antioxidant compounds - in order to lead finding. Research Journal of Pharmaceutical, Biological and Chemical Sciences, 4(2), 876-881.

Yilmaz, N. K., Swanstrom, R., \& Schiffer, C. A. (2017). Improving Viral Protease Inhibitors to Counter Drug Resistance, 24 (7), 547-557. https://doi.org/10.1016/j.tim.2016.03.010

Zubair, M. S., Anam, S., Khumaidi, A., Susanto, Y., Hidayat, M., \& Ridhay, A. (2016). Molecular Docking Approach to Identify Potential Anticancer Compounds from Begonia (Begonia sp). Advances of Science and Technology for Society, 080005, 1-7. https://doi.org/10.1063/1.4958513. 